\title{
Risk management program in the Port of Santos, Brazil: an ecosystem's perspective
}

\author{
I. R. F. Poffo ${ }^{1}$, J. C. M. Xavier ${ }^{2}$, Y. Schaeffer-Novelli ${ }^{3}$ \\ \& G. Cintrón ${ }^{4}$ \\ ${ }^{1}$ Program of Environmental Science of the São Paulo University and \\ CETESB, São Paulo, SP, Brazil \\ ${ }^{2}$ CETESB, São Paulo, SP, Brazil \\ ${ }^{3}$ Program of Environmental Science and Oceanographic Institute of the \\ São Paulo University, São Paulo, SP, Brazil \\ ${ }^{4}$ Division of International Conservation, \\ US Fish and Wildlife Service ARLSQ, Arlington, U.S.A.
}

\section{Abstract}

The Port of Santos, the largest and fastest growing seaport in Brazil, lies within a sheltered, mangrove-lined estuary. The movement of dangerous chemicals is a hazardous activity which could generate severe negative socio-environmental impacts. From an ecosystem perspective, the port may be perceived as part of an integrated web of economic, ecological, legal, social systems and not as a mere industrial complex, isolated from the sensitive ecosystems surrounding it; or from the people who work in and reside in the region. We emphasize the integrated concept of humans-in-nature, adopting the view that the distinction between social and natural systems is artificial and arbitrary. This paper presents an assessment of the linkages between the causes and consequences of environmental incidents which occurred between 1980 and 2006; a period during which 108,934 ships berthed. Four hundred and twenty-four entries were compiled from CETESB's (the Environmental Agency of São Paulo State), CODESP's (the port authority) and ABTL's (the Brazilian Association of Liquid Bulk Terminals) database. The results demonstrate that maritime transport accounted for the great majority of the spills which were mainly provoked by operational failures. Marine fuel oils (bunkers) were released more frequently than any other chemical substance and in the majority of the cases, the oil spread well beyond the spill site, impacting the health and safety of people and ecosystems of the region. The preventive and corrective actions which were taken had positive effects, highlighting the importance of enhancing resilience to reduce impacts and accelerate recovery.

Keywords: risk management, oil and chemical spills, ecosystemic point of view, Port of Santos, Brazil. 


\section{Introduction}

We have much to learn regarding environmental incidents - mainly the major incidents in ports - in order to improve scientific and technical knowledge to support planning, enforcement, prevention and response actions; as well as to protect ecologically susceptible areas. It is essential to review the past to better understand the present in order to minimize risk, facilitate safe and productive operations and accelerate natural recovery after an incident.

Proactive prevention based on experience provides protection from inherent risks and addresses coastal vulnerabilities to reduce or mitigate impacts. A characteristic of a resilient community is that it learns from past experience and adapts to change based on lessons learned. Prevention, based on experience is beneficial to the coastal management as well as to the general public. Prevention is not only common sense; it makes economic sense.

The Port of Santos, the biggest in Brazil, a gateway to the most heavily industrialized southwest and central-west regions is located in the Brazilian central coast $\left(25^{\circ} 53^{\prime}\right.$ South $46^{\circ} 19^{\prime}$ West $) 90 \mathrm{~km}$ from São Paulo city, the economic capital of the country (Fig.1).

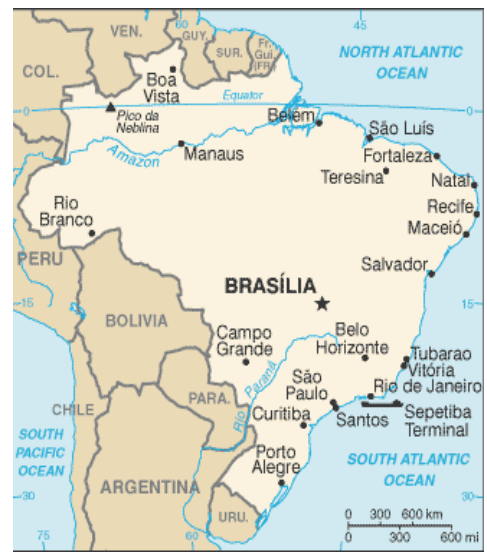

Figure 1: $\quad$ Port of Santos localization.

Today, the port has a yearly throughout volume of more than 42 millions tons of diverse cargoes within its $12 \mathrm{~km}$ wharf (both margins) of public and private terminals. These include dry bulk, liquid bulk, such as chemicals and petrochemicals substances, vehicles and passengers.

Port development has had serious environmental impacts because the area is located within a well-sheltered estuary region dominated by mangrove forests that are the core of a very sensitive aquatic ecosystem that has substantial ecological and socioeconomic values.

Incidents are unavoidable; there are inherent risks involved in any marine operation. Numerous oil and chemical spills have occurred in this region (mainly during the 1980s) from pipelines, chemical and petrochemical terminals, ships 
and barges. These have had significant negative consequences to human lives and to the quality of the marine environment.

The analysis presented aims to help reduce risks of incidents and improve the system by discussing the causes and consequences of environmental incidents within the spatial domain of the port region of Santos from 1980 to 2006. Longterm analysis allows a better understanding of the evolving dynamics of a busy and expanding port. An integrated perspective that includes public policies and legal framework and economic development recognizes the interdependence of the natural, social and political domains.

The results reveal long-term trends useful for contingency planning, emergency response planning and coastal management. This knowledge may be used to avoid marine pollution by identifying flaws and imperfections in decision making processes; including operational gaps, mistakes and unexpected outcomes. By addressing weaknesses and replicating effective practices, risks and vulnerabilities could be reduced; accelerating emergency responses and speeding recovery, that is, the system's resilience and robustness.

\section{Methods and procedures}

CETESB, the environmental authority of the São Paulo State, maintains a regional database of accidental oil and chemical spills from tankers, combined carriers, barges, chemical and petrochemical terminals, pipelines, road and railway transports. This database is used to generate statistics on numbers and size of spills, the kind of products spilled and causes.

Similar work has been done by CODESP, the port authority of the São Paulo State, for port operations, and by ABTL, association of the Brazilian liquid bulk terminals, involving chemical and petrochemical incidents. CETESB, CODESP and ABTL's database were the source of the information used to study the causes and consequences of discharges in the port region of Santos from 1980 to 2006.

This research builds upon earlier work done in 2000 to study the environmental impacts of the largest oil maritime terminal in the Brazilian coast (the São Sebastião Terminal from 1974 to 1999) which receives almost 51\% of all the crude oil that enters the country. This terminal is located in the coast of São Paulo but is further north. In both instances, the number of the occurrences was normalized in accordance with the yearly number of berthed ships during the study period.

Here, the occurrences are classified based on the source of the discharges, as maritime transport (tankers, other kind of vessels, barges, and tugboats), chemical and petrochemical terminals, container terminals, public and private port, pipelines and slicks of those of unknown origin (mysterious spills or unidentified source). The failure modes' classification was operational, mechanical and natural causes among others.

Consequences studied physical and chemical properties of oil and other hazard and noxious substances, which leakage can create hazards to human health, to harm living resources and marine life and other uses of the estuary. The 
amount of oil and chemical spilt, slicks displacement in Santos' Port Channel, human and aquatic toxicity and socioenvironmental impacts.

The following bibliography references were consulted as theoretic background: Branco [1], Kennish [13], Schaeffer-Novelli [19], Capra [2], Kasperson et al. [12], Christou [5], Poffo [18], Leschine [14], Nardocci [17] and Lovelock [16]. And also basically the websites of: GESAMP (the Group of Experts on Scientific Aspects of Marine Environment Protection) [7], USEPA (Environmental Protection Agency of United States of America), IMO (International Maritime Organization) [10], ITOPF (International Tankers Owners Pollution Federation) [11] and Brazilian national webs.

\section{Results}

The total number of occurrences in these 27 years was 424, during which time 108,934 ships berthed in the Port of Santos. Analyzing the data, a variation in the record number is observed (table 1).

Table 1: General relation of the causes of the occurrences by source.

\begin{tabular}{|c|c|c|c|c|c|c|c|c|}
\hline Period & Reg. & $\begin{array}{l}\text { Norm } \\
\text { number }\end{array}$ & $\begin{array}{l}\text { Cont } \\
\text { Term. }\end{array}$ & $\begin{array}{l}\text { P \& P } \\
\text { ports }\end{array}$ & Pipe & $\begin{array}{l}\text { Chem. } \\
\text { Term. }\end{array}$ & Vessel & $\begin{array}{l}\text { No Id. } \\
\text { spots }\end{array}$ \\
\hline $\begin{array}{l}1980 \\
1984\end{array}$ & 11 & 0,77 & 0 & 0 & 3 & 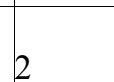 & 6 & 0 \\
\hline \begin{tabular}{|l|}
1985 \\
1989 \\
\end{tabular} & 101 & 5,38 & 4 & 7 & 1 & 25 & 57 & 7 \\
\hline \begin{tabular}{|l|}
1990 \\
1994 \\
\end{tabular} & 55 & 2,95 & 2 & 4 & 3 & 14 & 17 & 15 \\
\hline \begin{tabular}{|l|}
1995 \\
1999 \\
\end{tabular} & 48 & 2,42 & 2 & 3 & 2 & 8 & 25 & 8 \\
\hline \begin{tabular}{|l|}
2000 \\
2004 \\
\end{tabular} & 154 & 6,86 & 12 & 14 & 0 & 12 & 33 & 83 \\
\hline \begin{tabular}{|l|}
2005 \\
2006
\end{tabular} & 55 & 4,93 & 10 & 5 & 0 & 3 & 14 & 23 \\
\hline Total & 424 & 3,89 & 30 & 33 & 9 & 64 & 152 & 136 \\
\hline
\end{tabular}

Legend: Reg.: register number; Norm. number: normalized data; Cont.term.: containers terminals; $P \& P$ ports: public and private ports; Pipe: pipelines; Chem. term.: chemical and petrochemical terminals; Vessels: any kind of vessels and No Id. Spots: spots of unknown origin (mysterious spills).

This variability can be explained considering the port as an action arena where the situation evolves from the interplay of economic, ecological, legal and social factors. For example, the number of occurrences was low between 1980 and 1984 when reporting requirements were weak, and there was poor reporting, particularly for small spills (less than $1 \mathrm{~m}^{3}$ ).

Between 1990 and 2000 occurrences remained low although two important events took place: a large administrative change in port management because of a new law (popularly referred to as the Ports Law), which increased vigilance 
and enforcement, and the introduction of the CETESB's Risk Management Program for some chemical and petrochemical terminals in this region.

During the Brazilian economical and industrial growth program (1985/1990), the number of berthed ships and cargo movements increased and concurrently the MARPOL Convention became internalized in the Brazilian legislation. The enforcement increased but occurrences increased. They increased again after 2000 during a new economic boom, in spite of the implementation of a new environmental law created ("the law of the oil spills"- n. 9,966/2000).

This law was enacted following one of the worst oil spills on the Brazilian coast which took place in Guanabara Bay, Rio de Janeiro, RJ, (January 2000). The law, based on the OPRC 90 Convention, orders the immediate reporting of any kind of oil spill or amount of spill, to the navy and environmental authorities, also orders the oil spills' contingency planning and improvements in facilities response capacity and the fines became very hard to the polluters.

Detailing these general statistics based on the source of the spills, figure 2 shows that the majority are associated with vessels' spills (36\%) and to slicks of unknown origin (mysterious spills) $(32 \%)$ and the minority (2\%) with oil pipelines.

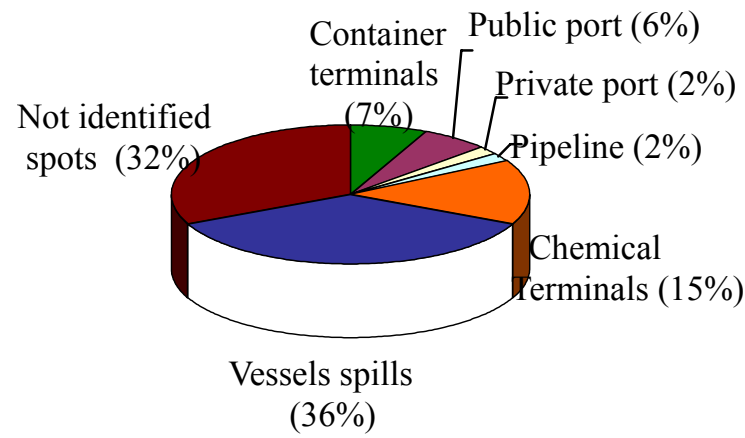

Figure 2: Annual and normalized distribution of the registered occurrences (1980-2006).

Table 1 also shows that there was a tendency for a decrease of the entries involving pipelines and chemical terminal discharges. This can be attributed to the success of prevention measures introduced by the Defense of the Coast Committee - CODEL, mainly between 1984 and 1985, and the CETESB's Risk Management Program applicable to oil pipelines and chemical/petrochemical terminals in the São Paulo’s coast - RMP - since 1989.

The database also indicates that the amount of oil and chemical spilled to the aquatic environment from these sources decreased. However, at the same time there was an increase of the entries involving container terminals, public and private ports, vessels and of mysterious spills, since 2000, just after "the law of the oil spills". These activities are not regulated by the CETESB's RMP. 
Considering failure modes, operational spills predominated, accounting for $50 \%$ of the total, followed by unidentified or mysterious spills $(24 \%)$ and mechanical failures (18\%). GILL [8] considers that the causes of all the accidents in the industries, operation of pipelines and ships among others, including the most dangerous occurrences are related to human error, and involve problems of ergonomics. Henderson [9] agrees partially with this assertion and highlights the necessity to evaluate operational failures adopting a systemic view and not a mechanistic one.

He considers that these failures evolve from the interaction of multiple factors involving individual failures, machine failures and organizational or institutional failures. It has been estimated that as many as $80 \%$ of marine incidents are a result of human error. It may be more correct to call these human and organizational errors because humans act within organizational structures. Understanding the role of human and organizational factors (HOFs) may provide insights as to causes of these incidents as well as ways to prevent them.

Analyzing causes and consequences of these spills, the operational failures evolve routines operation such as oil and chemical loading/unloading procedures and during bunkering by barges. ITOPF statistics presents a very similar result for oil and chemical spills in marine environment (www.itopf.com /information/statistics.causes).

These activities account for most of the small spills or less than $8 \mathrm{~m}^{3}$ (the amount adopted for this paper based on Brazilian legislation) while ITOPF considers the amount classification as less than 7 tones. In comparison, accidents such as collisions and groundings accounted for the largest oil spills being equal or more than $200 \mathrm{~m}^{3}$ (more than 7,000 tons for ITOPF).

Although the number of occurrences increased after 2000, the amount of oil and chemical spills had decreased since 1990. This suggests that the CETESB's RMP and the ABTL's measures had been effective, and had brought improvements in prevention and in the quality of spills response.

For small spills, (less than $8 \mathrm{~m}^{3}$ ), oil slicks had a tendency to remain confined; spreading only along the immediate surrounding area, but remaining close to the source of the spill causing local and low environmental impacts. Larger spills spread for longer distances, and caused regional and high environmental impacts, mainly to the mangroves. Significantly, no large spills have occurred since the 1990s.

In relation to their properties, 48 different types of hazardous and noxious substances were identified in these environmental accidents, 24 were classified as flammable; 11 as toxic and 4 as very toxic to human health. For aquatic life, 10 were classified as slightly toxic, 7 as toxic; and 12 as causing visual impacts. Because of their visual impacts, oil spills and oil spill residues cause significant public disquiet.

An assessment of the socioenvironmental impacts shows that the most significant were:

1. respiratory discomfort for the port's, chemical and petrochemical terminals operators due to the toxic clouds created by volatile products spills such as benzene, toluene, petroleum liquefied gas, ciclopentane and gasoline; 
2. fear and panic to the operators and to the surrounding community, after fires, such as those which occurred after a gasoline pipeline spill in Socó Village (a very poor community); after explosions in the chemical terminals in Barnabé Island, and after a fire in a container terminal;

3. numerous deaths and injuries due to the incident in the Socó Village, and one death due to the explosion in Barnabé Island;

4. persistent environmental damages to the mangrove forests due to oil and other chemical substance spills (including tallow), and the fires in Barnabé Island;

5. contamination of sand beaches, rocks, boulders and man-made structures including the port's artificial structures, jetties as well as mooring lines and ship hulls;

6. mortality of estuarine and marine fauna/flora and mangrove trees;

7. damage to the Santos' tourism and to leisure activities like surfing, sailing and other aquatic sports and in waters of the Santos Bay and in its beaches due to oil spills and clean-up/recovery operations;

8. damage to the fishing activities; boats and gear, floating equipment nets and ropes; reduced catches due to reductions in fishing effort;

9. negative impacts due to the clean-up operations on mangroves, sandy beaches and rocks, and inappropriate techniques and inadequate organization which was common in 1980s and mid of 1990s. For instance, on scene commanders were not used to paying attention to tidal and weather influences on the slicks' displacement and did not take care of the mangroves' vulnerability.

Large amount of contaminated (and also non-contaminated) sand was removed unnecessarily along with contaminated sand and debris. Sandy beaches are vulnerable because heavy machinery causes the oil to become dug-into the sand increasing contamination of the substrate and its persistence. Heavy equipment tends to mix oil into the sand forcing the removal of more sand.

\section{Final considerations}

In general, a reduction in the frequency of regional impact incidents has been observed since the $1980 \mathrm{~s}$ and beyond to the 1990s. Large $\left(200 \mathrm{~m}^{3}\right)$, spillages have not occurred since 1999. This suggests that the improvements in prevention and response capacity have been accomplished by the efforts of the environmental agencies, the chemical terminals, and CODESP.

Examples of human and organizational investments include: risk analysis studies, emergency planning, identification and mapping of susceptible areas and agreement on priorities for protection, as well as acquisition of response equipment appropriate for oil and chemical spills.

Training has been a core component of prevention. Training for technicians includes familiarization with, and understanding of the specific practices and goals of CETESB's RMP as well as increasing environmental awareness related to appropriate response actions as well as the development of response exercises (simulations and scenarios). 
In the scope of the RMP, the ABTL Emergency Integrated Plan, should be highlighted because it considers chemical as well as oil spill responses within the port region and the estuary. This extension of the RMP initiative considers human fatalities (expressed as individual or social risk), as well as a first step to socio environmental impacts.

This study also suggests greater investments in environmental protection through a people-focused approach that addresses the root cause of most accidents; the human element. This involves enhanced training programs and qualification of the operators, as well as provision of a well engineered working environment in order to minimize the operational failures, ecological and socioenvironmental impacts. Such approach, based on risk avoidance and management must be based on anticipation, identifying and evaluating foreseeable risks.

Improvements in the change of companies' mentality related to the environment were demonstrated by the study, comparing the actions of prevention and response that were carried through in the years 1980s to $1990 \mathrm{~s}$ and after 2000s when they became committed to the minimization of the impacts onto susceptible areas.

The procedures developed by CETESB, in the late 1990s, for clean up operations of coastal environments affected by oil spills were consolidated in a manual (Lopes et al. [15]) that has contributed significantly to training and to change negative proceedings.

The news releases by television and newspapers covering major accidents involving fires and explosions with ships, pipelines and terminals created panic situations and eroded the credibility of environmental agencies, the industry and the previous work and advances made in improving safety, giving the false impression that the safeguards promoted had not succeeded.

It is very important to improve this situation through continued engagement with local communities and improved communications using new technologies such as the web. Dialogue with the community is crucial for engagement of all stakeholders in an area in order to provide for risk reduction and accelerated natural recovery from incidents.

These findings highlight the necessity for greater investment in a peoplefocused, socio environmental risk management initiative that considers risk perception and risk communication, environmental education, special courses about environmental accidents for educators and journalists as well as other professionals. At the same time it is very important to prepare the community for emergency situations, work with community awareness emergency response. In fact, there is a lot of work to do; resilience requires developing integrated and holistic prevention and management programs!

\section{Conclusion}

This historic study of Santos' Port Complex demonstrated the diverse links that exist between the causes and consequences of environmental incidents. It demonstrates that international conventions, such as MARPOL 78 and OPRC 90, 
coupled with effective national legislation and complementary public policies such as CETESB's RMP have the capability to improve preventative measures, response capacity and to minimize estuarine and marine pollution. It also highlights that a safe marine environment is a product of a balance between private terminal operators, and public ports but that marine safety is also a primary concern for vessel operators and ship crews.

\section{References}

[1] Branco, S. M. Ecosistemic: an integrated overview of environmental problems. Editora Edgard Blücher Ltda. Brazil, São Paulo, SP. $1^{\text {a }}$ Edition, 202p. 1989.

[2] Capra, F. Mutation Point and The Web of Life. São Paulo, SP. Editora Cultrix; 256 p. 1996.

[3] CETESB: www.cetesb.sp.gov.br - http://www.cetesb.sp.gov.br/emergencia/ acidentes/vazamento/vazamento.asp

[4] CETESB. Risk Management Program (PGR - Programa de Gerenciamento de Riscos em Dutos e Terminais da Baixada Santista e Litoral Norte). www.cetesb.sp.gov.br/emergencia/riscos/documento/relatorio_GT_terminai s.pdf

[5] Christou, M.D. Substances Dangerous for the Environment in the context of Council Directive 96/82/EC. Report by Technical Working Group 7. Joint Research Centre European Commission. CHRISTOU M.D. Editor, 2000.

[6] CODESP. Port of Santos History (História do Porto de Santos). www.novomilenio.inf.br/porto/portoh00.htm

[7] GESAMP: www.gesamp.net

[8] GILL, D.W. Human Error and Hazard Studies. In V Encontro Técnico sobre Engenharia da Confiabilidade e Análise de Risco, RJ/RJ - Vol. 1. Trabalhos técnicos. P.1-10. Petrobras. 248pp.). 1997.

[9] Henderson, D.E.J. Identifying the direct and underlying human causes of accidents: Developing an evidence base to prioritise accident reduction efforts. In Encontro Internacional de Confiabilidade Humana PETROBRAS - Rio de Janeiro, RJ. - CD. 2004.

[10] IMO: www.imo.org/marineenvironment

[11] ITOPF. Response to marine oil spills. Witherby \& The International Tanker Owners Pollution Federation. London. (UK). 1986.

[12] Kasperson, R. E.; Renn, O.; Slovic, P.; Brown, H.S.; Emel, J.; Goble, R.; Kasperson, J.; Ratick, S. The Social Amplification of Risk: A Conceptual Framework. Risk Analysis. Vol. 8. No. 2; p. 177-187. 1988.

[13] Kennish, M. J. Ecology of Estuarines: Anthropogenic Effects. CRC Press Bocan Roxton. 1992.

[14] Leschine, T.M. Oil Spill Science and the Social Amplification and Attenuation of Risk. Working Paper Series 2001-09. Oil Spill Science and Technology Bul.;34p. June, 2001.

[15] Lopes, C.F., Milanelli, J. C. and Poffo, I. R. F. Coastal Environments polluted by oil: clean up proceedings (Ambientes costeiros contaminados 
por óleo: procedimentos de limpeza - Manual de Orientação). LOPES. C. F. (org). São Paulo: Secretaria de Estado do Meio Ambiente. 120pp. 2007. http://www.cetesb.sp.gov.br/emergencia/artigos/artigos_manual.asp

[16] Lovelock, J. Gaia: Medicine for an ailing planet. Ed. Cultrix. 192pp. 2006.

[17] Nardocci, A. C. Social Risk Management. Revista de Direito Sanitário. Vol. 3 - No.1 - março de 2002. São Paulo, SP; p.65-78. 2002.

[18] Poffo, I.R.F. Oil Spills in the North Coast of São Paulo State (Vazamentos de Óleo no Litoral Norte do Estado de São Paulo). Análise Histórica (19741999). Dissertação de Mestrado. PROCAM/USP, 2000.

[19] Schaeffer-Novelli, Y. Vulnerability of North Coast of São Paulo State to crude oil and refined oil spills (Vulnerabilidade do litoral norte do Estado de São Paulo a vazamentos de petróleo e derivados). In II Simpósio sobre Ecossistemas da Costa Sul e Sudeste Brasileira. Síntese de conhecimentos. S P: Academia de Ciências do Estado, (2), p.375-399. 1990. 